Available online at http://jurnal.stmikroyal.ac.id/index.php/jurteksi

\title{
SISTEM PAKAR BERBASIS WEB MENGGUNAKAN METODE FORWARD CHAINING DALAM MENGANALISA KERUSAKAN MESIN FOTOKOPI DAN PENANNGGULANGANNYA (STUDY KASUS DI Q-EL COPIER SERVICE CENTER AND DISTRIBUTOR)
}

\author{
Refli Noviardi \\ Program Studi Sistem Informasi, Institut Teknologi Batam \\ email: reflynov@gmail.com
}

\begin{abstract}
A copier is a machine used to duplicate documents in the form of paper that will be used for various purposes, the high need for a photocopier makes the operation of the machine very high for a long time. This situation makes the engine to be down and easily damaged. A photocopier is a complex machine that is interconnected with one another, so expert handling is needed to repair it. The limited number of technicians makes old machines that are old to be repaired, so we need a system that can replace the position of experts in repairing copiers. The expert system is a computer-based system that adopts the workings of experts in analyzing a problem with methods that have been adapted to existing problems, based on the problems outlined above. The purpose of this research is how to create an expert system application with a Forward Chaining method to analyze machine damage and provide solutions to repair the photocopier.
\end{abstract}

Keyword: Expert System; Damage analysis; Forward Chaining; Photocopy Machine

\begin{abstract}
Abstrak: Mesin fotokopi merupakan mesin yang digunakan untuk menggandakan dokumen dalam bentuk kertas yang akan digunakan untuk berbagai keperluan, tingginya kebutuhan akan mesin fotokopi ini membuat pengoperasionalan mesin sangat tinggi dalam waktu yang lama. Keadaan ini membuat kondisi mesin menjadi turun dan mudah mengalami kerusakan. Mesin fotokopi merupakan salah satu mesin yang kompleks yang saling berhubungan satu sama lain, sehingga perlu penanganan ahli dalam memperbaikinya. Keterbatasan jumlah teknisi membuat mesin yang rusak lama untuk diperbaiki, sehingga diperlukan sebuah sistem yang dapat menggantikan posisi pakar dalam memperbaiki mesin fotokopi. Sistem pakar merupakan sistem yang berbasis komputer yang mengadopsi cara kerja pakar dalam menganalisa suatu masalah dengan metode yang telah disesuaikan dengan masalah yang ada, berdasarkan masalah yang telah dijabarkan diatas. Tujuan dari penelitian ini adalah bagaimana menciptakan sebuah aplikasi sistem pakar dengan metode Forward Chaining untuk menganalisa kerusakan mesin dan memberikan solusi untuk memperbaiki mesin fotokopi tersebut.
\end{abstract}

Kata Kunci: Analisa Kerusakan; Forward Chaining; Fotokopi; Sistem Pakar. 
JURTEKSI (Jurnal Teknologi dan Sistem Informasi)

Vol. 6 No. 2, April 2020, hlm. 163 - 172

DOI: https://doi.org/10.33330/jurteksi.v6i2.548

Available online at http://jurnal.stmikroyal.ac.id/index.php/jurteksi
ISSN 2407-1811 (Print)

ISSN 2550-0201 (Online)

\section{PENDAHULUAN}

Komputer pada awalnya ciptakan hanya untuk kalangan tertentu saja, seperti kalangan akademisi dan militer dan pada perkembangannya computer digunakan diseluruh sektor, sehingga dalam perkembangannya computer di rancang utuk membantu pekerjaan manusia bahkan dirancang bekerja layaknya manusia [1]. Kemampuan komputer seperti mengingat dan menyimpan data yang sangat handal membuat manusia sangat terbantu dalam proses mengolah data [2], dan konsultasi terhadap sesuatu dengan orang yang ahli dibidangnya akan menemukan solusi yang sangat tepat terhadap masalah yang ditemui [3].

Sistem pakar merupakan bagian dari perkembangan yang ada didalam teknologi informasi, bagian dari ilmu komputer yaitu kecerdasan buatan yang mana dalam proses operasionalnya sistem ini mengadopsi cara berpikir manusia. dimana sistem pakar dirancang dengan tujuan membantu manusia dalam mengambil sebuah keputusan [4]-[6] dan sistem pakarpun bisa menjadi sebuah konsultan terhadap orang yang non pakar, yang menggabungkan antara pengetahuan dengan penelusuran data dalam prosesnya untuk membantu mengambil sebuah keputusan dari masalah yang timbul sehingga dapat dipecahkan secara efektif dan efisien [7]-[9].

Dokumen merupakan sesuatu yang sangat penting dalam kehidupan sehari-hari karena fungsinya yang beragam dan dipakai dari segala sector kehidupan untuk memenuhi kebutuhan masing-masing individu atau kelompok [10].

Mesin fotokopi merupakan mesin yang digunakan untuk meng- gandakan dokumen dalam bentuk Hard Copy atau kertas untuk berbagai keperluan di dalam masyarakat[10]. Kebutuhan akan penggandaan dokumen membuat pemakaian mesin fotokopi sangatlah tinggi. Mesin fotokopi juga merupakan mesin yang memiliki banyak komponen didalamnya, sehingga dibutuhkan seorang teknisi yang bisa tahu akan kerusakan mesin ini. Ketersediaan teknisi di kota Padang juga sangat terbatas sehingga dibutuhkan sebuah sistem yang dapat menggantikan peran teknisi dalam meganalisa kerusakan dan memberikan solusinya. Berdasarkan masalah diatas peneliti merumuskan penelitian ini adalah bagaimana cara menganalisa kerusakan mesin fotokopi menggunakan metode Forward Chaining dan bagaimana mengaplikasikannya ke dalam sebuah aplikasi berbasis web. Mengapa kita menggunakan aplikasi berbasis web. Web browser itu sendiri menyediakan layanan yang menerima dan menampilkan informasi secara online [11].

Adapaun tujuan penelitian ini adalah untuk membuat sebuah rancangan sistem pakar yang yang menggunakan metode Forward Chaining sehingga operator mesin (non pakar) dapat menganalisa kesalahan dan mendapatkan instruksi untuk memperbaiki error pada mesin tersebut.

Kecerdasan buatan atau yang lebih dikenal dengan sebutan artificial intelegence.merupakan sebuah cabang imlu dalam ilmu computer yang mengkombinasikan antara perangkat keras dan perangkat lunak yang dirancang sedemikian rupa sehingga dapat berpikir layaknya seorang manusia berpikir, dan cara seorang berikir ini dapat di artikan sebagai sebuah sistem pakar[12] 
JURTEKSI (Jurnal Teknologi dan Sistem Informasi)

Vol. 6 No. 2, April 2020, hlm. 163 - 172

DOI: https://doi.org/10.33330/jurteksi.v6i2.548

Available online at http://jurnal.stmikroyal.ac.id/index.php/jurteksi

Komponen yang terdapat dalam sebuah sistem pakar terbagi menjadi 4 bagian yang dapat dijelaskan seperti pada penjelasan berikut ini:

1. Knowledge Base (Basis Pengetahuan) Basis pengetahuan merupakan sesuatu yang vital dalam komponen sistem pakar yang berisikan pengetahuan yang nantinya akan menjadi sebuah presentasi pengetahuan didalam sebuah database.

2. Working Memory (Basis Data atau Memori Kerja)

Merupakan bagian yang terdapat fakta-fakta yang digunakan didalam sebuah sistem pakar untuk memproses data sehingga mendapatkan sebuah kesimpulan atau hasil yang dipakai selama pengoperasian sistem yang tersimpan dalam memori kerja .

3. Inference Engine (Mesin Inferensia) Inference Engine adalah merupakan tata cara yang digunakan oleh seorang pakar dalam bentuk penalaran atau cara berpikir seorang pakar sehingga menghasilkan sebuah keputusan yang efektif dan maksimal dalam memecahkan sebuah masalah dimana cara berpikir ini disamakan dengan kaidah-kaidah yang ada dalam database yang berisikan sebuah basis pengetahuan .

4. User Interface (Antarmuka Pemakai)

Antarmuka pemakai adalah merupakan bagian yang menjembatani antara sistem dengan user atau pengguna. Dimana sistem telah dirancang sedemikian rupa berdasarkan berdasarkan fakta-fakta dan pemikiran seorang pakar. pada tahap ini user atau pengguna dapat melakukan interaksi dengan sistem layaknya sebuah percakapan yang ada antara seorang pakar dengan user 
JURTEKSI (Jurnal Teknologi dan Sistem Informasi)

Vol. 6 No. 2, April 2020, hlm. 163 - 172

DOI: https://doi.org/10.33330/jurteksi.v6i2.548

Available online at http://jurnal.stmikroyal.ac.id/index.php/jurteksi

pengolahan data dalam penelitian ini dapat dipertanggung jawabkan dan dijadikan sebagai jawaban atau suatu pemecahan masalah dalam penelitian ini. Penelitian ini sendiri sejatinya berada pada sebuah perusahaan yang bergerak dalam bidang pengadaan mesin fotokopi dan juga sebagai tempat reparasi mesin fotokopi yang besar yang ada di kota padang yaitu Q-EL copier dan service and distributor. Ditempat ini memiliki banyak sekali teknisi-teknisi yang setiap hari menerima keluhan konsumen mesin fotokopi yang ada dikota padang, teknisi yang berada ditempat ini memiliki standart yang berbeda-beda sesuai dengan pengalamannya masing-masing dan keikutsertaan dalam pelatihan-pelatihan.

\section{HASIL DAN PEMBAHASAN}

Sistem pakar merupakan sebuah sistem yang dirancang yang menggunakan pemikiran seorang ahli didasari oleh masalah yang ditemukan dilapangan yang dapat membantu seorang nonpakar atau user dalam menyelesaikan masalah yang terjadi sesuai dengan kepakaran seorang ahli. Begitu juga dengan Sistem Pakar yang dalam rancang ini, merupakan Sistem Pakar yang dapat mengalisa kerusakan pada mesin fotokopi yang memiliki bagian-bagian yang cukup kompleks.

Kerusakan pada mesin fotokopi ini dapat terbagi menjadi 2 bagian, yaitu kerusakan pada hasil dan sistem pengoperan (sensor-sensor dan suku cadang). Kerusakan pada hasil merupakan kerusakan yang sering terjadi karena pemakaian mesin yang sering dalam waktu yang lama membuat kualitas hasil fotokopi menjadi berkurang, kerusakan pada hasil fotokopi terkadang berhubungan satu sama lain yang mengakibatkan seorang operator menjadi bingung, sehingga membutuhkan suatu kemampuan seorang pakar atau teknisi dalam memperbaikinya. Sistem pakar merupakan suatu solusi yang tepat dalam membantu user atau non pakar dalam membantu menganalisa kerusakan mesin fotokopi dan mengetahui caracara penganggulangannya [16], [17].

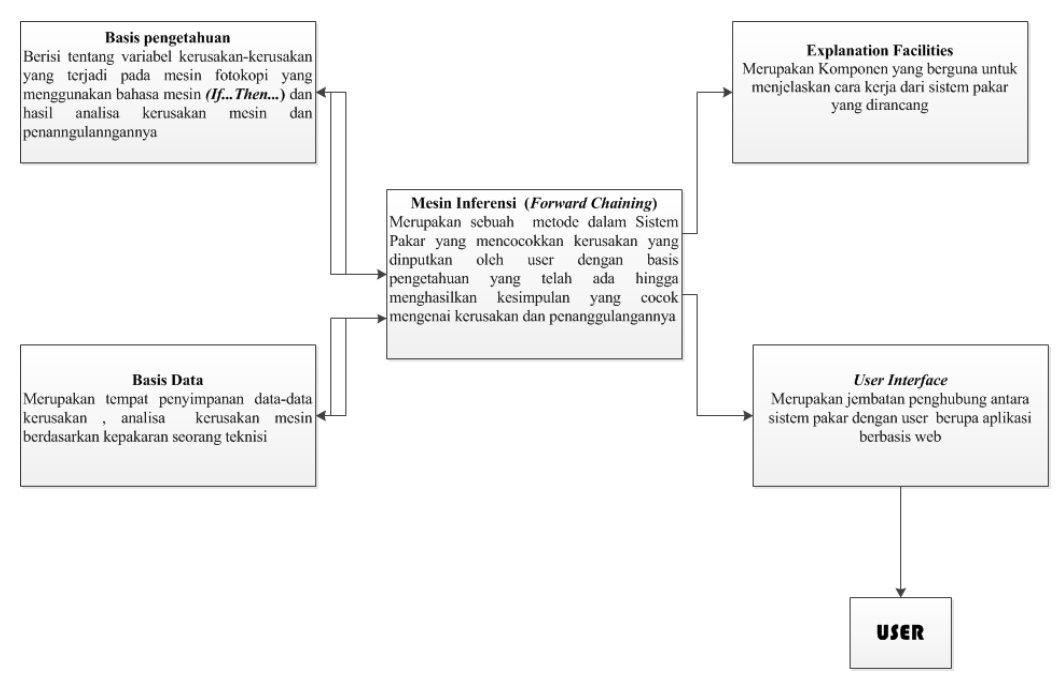

Gambar 1. Desain Arsitektur Sistem 
Available online at http://jurnal.stmikroyal.ac.id/index.php/jurteksi

Pembuatan Sistem Pakar dalam menganalisa kerusakan mesin fotokopi ini adalah dengan melakukan observasi langsung ketempat pakar atau teknisi fotokopi ini memperbaiki kerusakannya dan melakukan wawancara untuk mendapatkan data tentang kerusakan mesin fotokopi dan bagaimana cara kerja seorang pakar dalam menganalisa kerusakan dan cara memperbaiki kerusakan tersebut.

\section{Desain Arsitektur Sistem Pakar Fotokopi}

Sama halnya dengan semua Sistem Pakar yang telah dirancang sebelumnya, sistem ini didesain menggunakan komponen yang ada untuk saling berhubungan satu sama lain, sehingga menciptakan sebuah arsitektur Sistem Pakar yang merupakan sebuah dasar dalam pembuatan sistem pakar itu sendiri. Berikut adalah gambaran arsitektur sistem pakar dalam menganalisa kerusakan mesin fotokopi , yang dijelaskan dalam gambaran arsitektur sistem pakar pada gambar 1 .

\section{Mekanisme Inferensi}

Berdasarkan basis data pengetahuan yang telah didapat berdasarkan fakta-fakta dan data-data. Mekanisme penelusuran yang akan dilakukan menggunakan metode Forward Chaining, dimana metode ini bekerja berdasarkan fakta-fakta yang telah didapatkan dilapangan atau pada saat pengoperasinalan mesin fotokopi yang diinputkan oleh user (operator) kedalam sistem dari fakta tersebut, akan ditelusuri atau dicocokan dengan rule yang telah ada sehingga menghasilkan konklusi atau kesimpulan tentang kerusakan yang dialami oleh mesin dan sistem juga akan mengeluarkan saran atau solusi terkait kerusakan mesin tersebut.

Dalam sistem pakar analisa kerusakan mesin fotokopi ini penyajian aturan atau rule menggunakan premis yang akan ditulis dalam bentuk IF dan konklusi dalam bentuk THEN. Dan pada prancangan basis pengetahuan Premis (IF) dikategorikan dalam bentuk jenis kerusakan dan Konklusinya (THEN) dalam bentuk diagnosa disertai dengan bagian, dan solusi.

\section{Rule/Keputusan}

If Kertas Bergelombang is True And If Kertas tersangkut di lantai 1 is true Then Diagnosa $=$ Lower Kering. And bagian = Lower and Solusi = Oleskan Lower dengan Silicon untuk membuat permukaan lower menjadi basah.

If Kertas sobek bagian tengah is True and Kertas terlipat is True, Then Diagnosa $=$ Kuku $/$ Claw Set Disposisi And Bagian = Kuku / Claw set And Solusi $=$ Perbaiki letak kuku / Claw Set atau ganti.

If Hasil Tidak Presisi (Horizontal) Is True . Then Diagnosa $=$ Karet Exit Polos / Tidak Bergerigi And Bagian= Karet Exit And Solusi = Ganti Karet Exit

If Hasil Tidak Presisi (Vertical) Is True, Then Diagnosa =Karet Separator Disposisi And Bagian=Karet Separator And Solusi $=$ Perbaiki Letak Karet Separator.

If Hasil Tidak Presisi Is True, Then Diagnosa $=$ Karet Register Disposisi And Bagian = Karet Register And Solusi $=$ Perbaiki Letak Karet Register.

If Hasil Bergaris Putih Is True And If Hasil Kabur is True And If Hasil 
Available online at http://jurnal.stmikroyal.ac.id/index.php/jurteksi

Kosong Is True, Then Diagnosa = Wire Kendur atau Putus And Bagian =Wire And Solusi $=$ Ganti Benang Wire. If Hasil Ramping Is True, Diagnosa = Elektronik CCD Bermasalah Bagian = Elektronik CCD And Solusi = Ganti Elektronik CCD.

If Kertas Menggulung Is True Then Diagnosa $=$ Kain Web Habis And bagian = Web And Solusi = Ganti Kain Web.

If Tinta Tidak Lengket Is True And If Hasil Tampak Bercak - Bercak Hitam Is True,Then Diagnosa = Roller Magnet Bermasalah And Bagian = Roller Magnet And Solusi = Bersihkan Roller Magnet Dari tinta, Kemudian Ratakan Tinta Kembali.

If Hasil Berbintik Is True And IF Hasil Kurang Tajam Is True And If Hasil Tidak Rata Is True And If Hasil Bergaris dalam Jumlah Banyak Is True Then Diagnosa $=$ Drum Kotor Bagian $=$ Drum And Solusi = Bersihkan drum dari goresan yang ada dengan Cairan pembersih.

If Hasil Mengambang Is True . Then Diagnosa Gear IT Disposisi And Bagian $=$ Gear IT And Solusi $=$ Perbaiki Letak Gear IT.

If Hasil Kotor is True And If Hasil Membayang Is True Then Diagnosa = Blade Bocor And bagian=Blade And Solusi $=$ Bersihkan Blade Dari Sisa-Sisa Pada Tinta Yang Menempal Menggunakan Alkohol Kemudian Pasang Kembali.

If Hasil Bergaris Hitam Lurus Is True, And Hasil Buram Is true Then Diagnosa = Kaca Scanner Kotor And Bagian
=Kaca Scanner And Solusi = Bersihkan Kaca Scanner Dengan Alkohol.

If Hasil Memiliki Garis Bergelombang Is True , Then Diagnosa = Tali Grade And Bagian= Tali Grade And Solusi = Kencangkan Kembali Tali Grade.

If Hasil Mengambang Is True .Then Diagnosa $=$ Sling Disposisi And Bagian $=$ Sling And Solusi = Perbaiki Letak Sling.

If kertas tersangkut di lantai 1 Is True and If kertas tersangkut di lantai 2 is true. Then Diagnosa $=\mathrm{Kuku}$ (Claw) disposisi And Bagian = Kuku (Claw) And Solusi = Perbaiki letak kuku.

If Hasil Muncul Setengah Is True And If Hasil terdapat Background Hitam Is True Then Diagnosa = Sensor Scanner Rusak And Bagian = Sensor Scanner And Solusi $=$ Setting Kembali Sensor Scanner Pada Sistem.

If Hasil bergaris Besar Ditempat yang Sama Is True . Then Diagnosa = Upper Tergores And Bagian = Upper And Solusi $=$ Ganti Upper.

If Kertas Tertarik Lebih Dari Satu Is True And If Kertas Tidak Tertarik Is True, . Then Diagnosa $=$ Sponge Roller Menipis And Bagian= Sponge Roller And Solusi $=$ Ganti sponge Roller.

\section{Implementasi Sistem}

1. Halaman Awal Aplikasi

Form halaman utama merupakan form yang pertama kali dilihat oleh user pada saat user mengaktifkan sistem ini. Pada halaman utama ini terdapat tiga tombol utama yang ada selain halaman awal yaitu tombol konsultasi dan tombol pakar. 
JURTEKSI (Jurnal Teknologi dan Sistem Informasi)

Vol. 6 No. 2, April 2020, hlm. 163 - 172

DOI: https://doi.org/10.33330/jurteksi.v6i2.548

Available online at http://jurnal.stmikroyal.ac.id/index.php/jurteksi
ISSN 2407-1811 (Print)

ISSN 2550-0201 (Online)

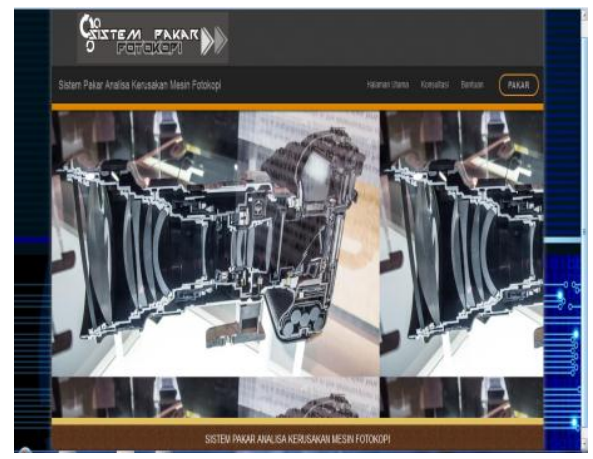

Gambar 2 Halaman Utama

\section{Halaman Pakar}

Halaman pakar merupakan halaman yang paling penting dalam sistem aplikasi ini karena dari halaman inilah pengetahuan pakar dalam bentuk rule, kerusakan dan analisaanalisa kerusakan mesin fotokopi akan diinputkan. Oleh karena itu hanya pakar yang bisa mengakses halaman ini dengan login terlebih dahulu dengan memasukkan nama dan password pada form login dan tekan tombol login.

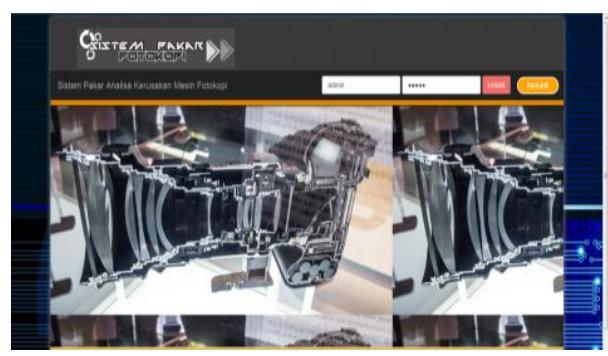

Gambar 3 Halaman Login Pakar

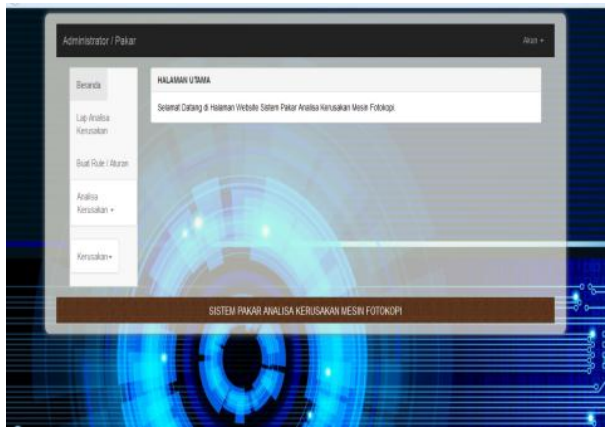

Gambar 4 Halaman Pakar
Didalam halaman pakar terdapat tombol-tombol yang digunakan untuk menginputkan data kerusakan, analisa kerusakan, dan tombol pembuatan rule. Data-data kerusakan mesin merupakan data yang pertama kali diinputkan oleh admin/pakar. Karena data kerusakan merupakan data yang akan diinputkan oleh user pada saat konsultasi, dari data kerusakan inilah nantinya akan ditelusuri apa analisa kerusakan yang terjadi pada mesin

3. Halaman Konsultasi

Halaman konsultasi merupakan halaman yang digunakan oleh user untuk melakukan konsultasi terhadap kerusakan mesin fotokopi. Sebelum melakukan konsultasi, user terlebih dahulu mengisi form nama sebagai langkah awal memasuki halaman konsultasi dengan cara menekan tombol konsultasi setelah itu isi nama dan tekan tombol lanjut.

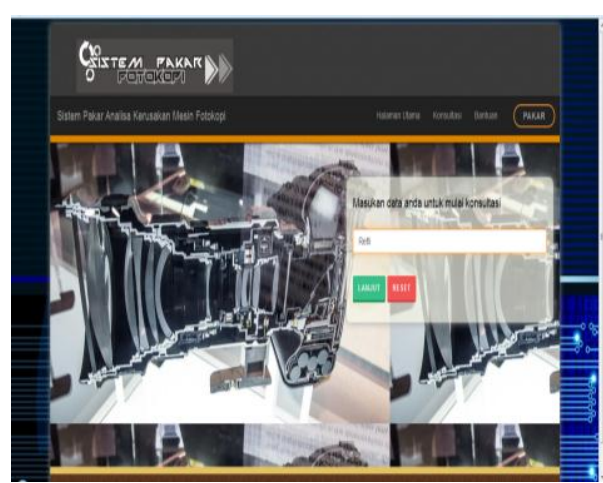

Gambar 5 Halaman pendaftaran konsultasi

Setelah menekan tombol lanjut. Sistem akan menampilkan halaman konsultasi seperti gambar 6 . 
JURTEKSI (Jurnal Teknologi dan Sistem Informasi)

Vol. 6 No. 2, April 2020, hlm. 163 - 172

DOI: https://doi.org/10.33330/jurteksi.v6i2.548

Available online at http://jurnal.stmikroyal.ac.id/index.php/jurteksi

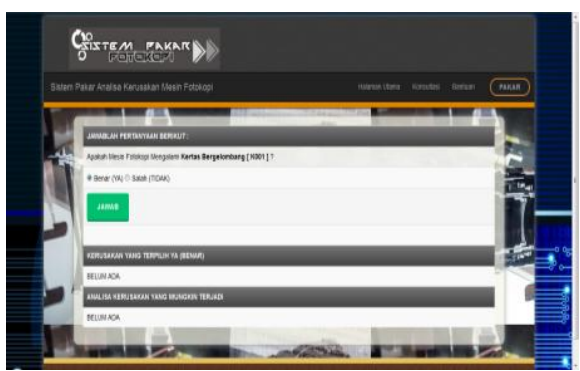

Gambar 6 Halaman Konsultasi

Pada halaman konsultasi ini user akan menemukan pertanyaan mengenai kerusakan-kerusakan yang telah diinputkan oleh pakar sebelumnya, user hanya akan menjawab antara benar atau salah. Setelah user menemukan kondisi yang sesuai dengan apa yang user alami, langkah selanjutnya adalah menekan tombol Jawab maka sistem akan mencocokkan denan rule yang telah dibuat sebelumnya dan sistem akan menampilkan hasil seperti gambar 7 .

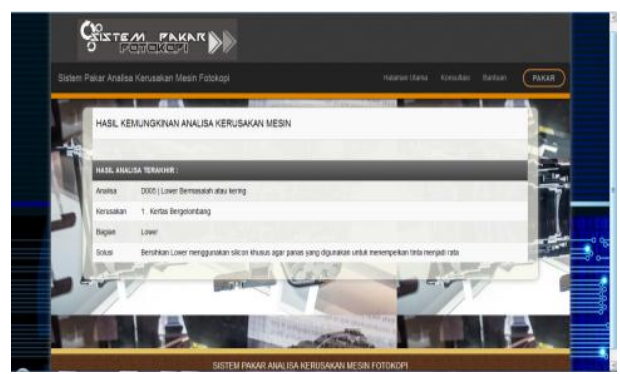

Gambar 7. Halaman Analisa Kerusakan

Setelah mendapatkan jawaban yang diinginkan, user dapat meninggalkan halaman konsultasi dengan menekan kembali tombol halaman utama. Untuk pakar sendiri terdapat halaman khusus yang dapat digunakan untuk melakukan perubahan terhadap sistem pakar seperti aturan berdasarkan perkembangan yang terjadi di lapangan.

\section{SIMPULAN}

Simpulan yang didapat selama melaku-kan penelitian ini adalah sistem pakar yang digunakan untuk membantu seseorang non pakar dalam menganalisa kerusakan mesin fotokopi dapat dilakukan. Dengan menggunakan metode Forward Chaining. Dan kerusakankerusakan yang terjadi pada mesin kebanyakan merupakan kerusakan yang berasal dari operasional mesin fotokopi dan kerusakankerusakan yang terjadi karena operasional mesin akan selalu mengalami muncul apabila suku cadag mesin fotokopi mengalami penurunan performa.

\section{DAFTAR PUSTAKA}

[1] M. J. Tobin, "Asthma, Airway Biology, and Nasal Disorders in AJRCCM 2003," Am. J. Respir. Crit. Care Med., vol. 169, no. 2, pp. 265-276, 2004.

[2] G. A. D. Sugiharni and D. G. H. Divayana, "Pemanfaatan Metode Forward Chaining Dalam Pengembangan Sistem Pakar Pendiagnosa Kerusakan Televisi Berwarna," J. Nas. Pendidik. Tek. Inform., vol. 6, no. 1, p. 20, 2017.

[3] N. Mukhtar and S. Samsudin, "Sistem Pakar Diagnosa Dampak Penggunaan Softlens Menggunakan Metode Backward Chaining," J. Buana Inform., vol. 6, no. 1, pp. 21-30, 2015.

[4] A. S. Wiguna and I. Harianto, "Sistem Pakar Diagnosa Kerusakan Sepeda Motor Matic Injeksi Menggunakan Metode Forward Chaining Berbasis 
Available online at http://jurnal.stmikroyal.ac.id/index.php/jurteksi

Android," SMARTICS J., vol. 3, no. 1, pp. 25-30, 2017.

A. D. Putri and D. Suhendra, "Sistem Pakar Untuk Mendeteksi Kerusakan Air Conditioner Menggunakan Metode Forward Chaining Berbasis Web," INOVTEK Polbeng - Seri Inform., vol. 1, no. 2, p. 148, 2016.

[6] D. P. Utomo and S. D. Nasution, "Sistem Pakar Mendeteksi Kerusakan Toner Dengan Menggunakan Metode Case Based-Reasoning. JURIKOM (Jurnal Riset Komputer)," JURIKOM (Jurnal Ris. Komputer), vol. 3, no. 5, 2016.

[7] W. Supartini and H. Hindarto, "Sistem Pakar Berbasis Web Dengan Metode Forward Chaining Dalam Mendiagnosa Dini Penyakit Tuberkulosis Di Jawa Timur," Kinetik, vol. 1, no. 3, p. 147, 2016.

[8] E. Wahyuni and W. Prijodiprojo, "Prototype Sistem Pakar untuk Mendeteksi Tingkat Resiko Penyakit Jantung Koroner dengan Metode Dempster-Shafer (Studi Kasus: RS. PKU Muhammadiyah YOGYAKARTA)," Berk. Ilm. MIPA, vol. 23, no. 2, p. 242752, 2013.

[9] M. Pangkey, V. Poekoel, and O. Lantang, "Sistem Pakar Pendeteksi Kerusakan Handphone Berbasis Android," J. Tek. Inform., vol. 8, no. 1, 2016.

[10] K. Manaf et al., "Sistem Pakar Untuk Mendiagnosa Kerusakan Mesin Fotocopy Canon IR 6000 Menggunakan Metode Certainty Factor," Pros. Semin. Nas. Ilmu Komput. dan Teknol. Inf., vol. 1, no. 1, pp. 333-339, 2018.

[11] I. Imron, M. N. Afidah, M. S. Nurhayati, S. Sulistiyah, and F. Fatmawati, "Sistem Pakar Diagnosa Kerusakan Mesin Sepeda Motor Transmission Automatic dengan Metode Forward Chaining Studi Kasus: AHASS 00955 Mitra Perdana," J. Ilm. Univ. Batanghari Jambi, vol. 19, no. 3, p. 544, Oct. 2019.

[12] A. Sunarya, S. Santoso, and W. Sentanu, "Sistem Pakar Untuk Mendiagnosa Gangguan Jaringan Lan," Creat. Commun. Innov. Technol. J., vol. 8, no. 2, pp. 111, 2015.

[13] "Jurnal Momentum ISSN : 1693752X SISTEM PAKAR PERAWATAN DAN PERBAIKAN RINGAN MOBIL BENSIN Jurnal Momentum ISSN : 1693-752X," vol. 16, no. 2, pp. 8-15, 2014.

[14] A. A. Rismayadi, "Perancangan Aplikasi Sistem Pakar Diagnosa Kerusakan Hardware Komputer Metode Forward Chaining," vol. 3, no. September, pp. 219-233, 2016.

[15] P. Adi and S. Purbawanto, "Sistem Pakar Untuk Mendiagnosa Kerusakan Televisi Dengan Metode Forward Chaining Menggunakan Php Dan Mysql," Edu Elektr. J., vol. 4, no. 2, pp. 27-34, 2015.

[16] D. Y. Prasetyo, "Prasetyo, D. Y. (2019). Sistem Diagnosis Kerusakan Mesin Fotocopy Canon iR 5000," JUTI UNISI, vol. 3, no. 2, pp. 1-9, 2019.

[17] J. S. Simatupang and E. Panggabean, "Sistem Pakar Untuk Mendiagnosa Kerusakan Mesin Fotocopy Canon IR 6000 
DOI: https://doi.org/10.33330/jurteksi.v6i2.548

Available online at http://jurnal.stmikroyal.ac.id/index.php/jurteksi

Menggunakan Metode Certainty

Factor. Jurnal Teknologi dan

Ilmu Komputer Prima

(JUTIKOMP)," J. Teknol. dan

Ilmu Komput. Prima, vol. 1, no.

2, pp. 61-66, 2018. 